\title{
TOM SWIFT'S THREE INVENTIONS OF TELEVISION
}

\section{MEDIA HISTORYANDTHETECHNOLOGICAL I MAG I NARY}

\author{
Doron Galili \\ Stockholms Universitet \\ Institutionen för mediestudier \\ Box 27062, 102 51, Stockholm \\ Sweden \\ doron.galili@ims.su.se
}

\begin{abstract}
The article discusses three fictional narratives of inventions of televisual devices, which appeared in a popular American boys' books series about a young inventor-adventurer in 1914, 1928 and 1933. It considers these narratives as representations of the 'technological imaginary' of television - that is, the ideas about the possibilities of the technology that were entertained before its material realization and informed its eventual formation. A comparison between the three different manners in which the novels depict the fictional inventions demonstrates how the early imaginaries of television were conceived and articulated in response to the continuously changing intermedial context of the early twentieth century.
\end{abstract}

Keywords: television, technological imaginary, Tom Swift, media archaeology, intermediality

The question of who invented television has famously been in dispute for many decades. Whereas media historians are cautious about designating 'firsts' and attributing such an invention to an individual, in popular stories about the arrival of television a considerable number of individuals have been credited with the title of 'the inventor,' 'the pioneer' or 'the father' of television. Some narratives, for example, regard the Scotsman John Logie Baird, who demonstrated early achievements in audiovisual transmission in the mid-1920s, as the inventor. According to other accounts, the real inventors might be Charles Francis Jenkins, who simultaneously experimented with a similar mechanical television in the United States, or the German Paul Nipkow, who already in the 1880s patented the scanning technology that eventually led to these pioneering achievements of the 1920s. Similarly, both Philo Farnsworth and Vladimir Zworykin, pioneers of the electronic television, technology are often regarded as inventors of television, because the systems they developed were deployed in the 1930s when large-scale dissemination of television started. ${ }^{1}$ This list can go on and on. Tracing the history of television further back to periods that preceded its material realization could lead to several nineteenth century imaginary conceptions of writers who, in a sense, 'invented' televisual media. Such is the case, for example, of illustrator George du Maurier, who published in 1878 a well-known cartoon of an 'electric camera obscura' 
that is sometimes considered (erroneously) as the first depiction of television - although Maurier himself attributed the imaginary invention to Thomas Edison.

But among the many people who have been credited as television's inventors, only one, to my knowledge, is attributed with three different inventions of television: Tom Swift, the fictional teenage inventor-adventurer and the protagonist of a remarkably successful American series of boys' books published between 1910 and 1941 (and succeeded by three follow up series that persisted until 2007). ${ }^{2}$ Each of the Tom Swift books dealt with a new machine that the young inventor conceived and fabricated: from an airship to a giant cannon and a floating airport. Remarkably, no less than three different books in the series focused on inventions in the field of visual transmission - and all of them preceded the inauguration of the first regular American television broadcasting services. In the 1914 novel Tom Swift and His Photo Telephone, the young inventor constructs a device that allows people to see over the phone the person to whom they are talking; in the 1928 Tom Swift and His Talking Pictures, he invents a large screen broadcasting system that delivers audiovisual entertainment to the home; and in the 1933 novel Tom Swift and His Television Detector, he invents a portable device that enables seeing in total darkness and through walls and other obstacles.

\section{Tracing the Technological Imaginary from an Intermedial Perspective}

In this article I discuss the three juvenile adventure novels as examples of the early popular technological imaginary of television. I borrow the term 'technological imaginary' from the work of French sociologist of technology Patrice Flichy, who has coined it to describe the initial ideas, dreams and utopias that inform future developments of technological inventions. According to Flichy, such ideas should be considered as "an integral part of the development of a technical system." ${ }^{3}$ As he notes, while the actual material construction of technological forms concerns primarily technicians and researchers, the conceptual construction of ideas about the possible designs and uses of technologies take place within discourses that involve larger and more varied social groups that include, among others, journalists and novelists. The technological imaginary is therefore an idea about the technology that circulates and is debated in society and may become, in turn, one of the resources available to inventors working on the construction of new technologies, "just as known physical phenomena or existing social practices are."4

The concept of the technological imaginary also proves useful in media historiography, since tracing the ways in which a certain technology was imagined may reveal the desires and purposes that its initial material development was aimed at fulfilling. Indeed, the study of imaginary concepts about inexistent media technologies became an important methodological concern for scholars of media archaeology who work on issues related to the origins and transformations of media forms. As Erkki Huhtamo writes, from the perspective of media archaeology, the study of "unrealized 'dream machines,' or discursive inventions (inventions that exist only as discourses), can be just as revealing as realized artifacts," since dreams and discourses are eventually imprinted on the technological media forms, and contribute to their media identity "in terms of socially and ideologically specific webs of signification."

To be sure, the narratives of Tom Swift's television inventions in question here delineate their social and ideological positions in a very unambiguous manner. As the dust jackets of the series' early volumes implicitly state, the books intended to "convey in a realistic way the wonderful advances in land and sea locomotion and to interest the boy of the present in the hope that he may be a factor in aiding the marvelous development that is coming in the future."6 Whether they genuinely aimed at encouraging the young readers to pursue training in engineering or merely tried to present themselves as concerned with such a noble goal, the books depicted the work of technical innovation not only as

2 Francis Molson, 'The Boy Inventor in American Series Fiction: 1900-1930,' Journal of Popular Fiction, 28, 1994, pp. 31-48.

3 Patrice Flichy, The Internet Imaginaire, MIT Press, 2007, p. 1.

4 Patrice Flichy, Understanding Technological Innovation: A Socio-technical Approach, Edward Elgar, 2007, p. 133.

5 Erkki Huhtamo, 'From Kaleidoscomaniac to Cybernerd: Notes toward an Archaeology of the Media,' Leonardo, 30, 3, 1997, p. 223.

6 Quoted in Robert Von der Osten, 'Four Generations of Tom Swift: Ideology in Juvenile Science Fiction,' The Lion and the Unicorn, 28, 2, April 2004, pp. 268-283. 
serving the public good but also as thrilling and financially rewarding. ${ }^{7}$ In this light, they display an unquestioned faith in the progressive potential of new technologies, which obviously limits their engagement with the cultural, scientific and economic conditions of innovations. Much like many other popular tales and myths of inventions, Tom Swift's inventions often originate in instantaneous 'eureka' moments or as a result of improbable accidents. The books provide only fairly basic explanations about the various technologies they feature, and those at times tend to be quite dubious and rely on popular inaccurate notions. In short, the little that the novels explicitly have to say about technological invention is precisely what the media historian should be wary of.

Nevertheless, I wish to argue that the three early television fantasies merit a serious consideration from a media archaeological perspective. As I demonstrate in this article, a comparison between the three novels' depictions of the inventions in question and the narrative framework in which they are embedded may shed new light on how the early imaginaries of television were conceived and articulated within the changing intermedial context of the early twentieth century. In particular, it is the serial nature of the Tom Swift televisual adventures that makes them an interesting case study for media historiography. By revisiting the scenario of the invention of image transmission devices three times during a period of two decades, the Tom Swift novels demonstrate how television's technological imaginary was not a constant and monolithic notion, but rather a historically transforming complex of ideas about mediated perception and communication that constantly responded to shifts in the media world that surrounded it.

My approach in the exploration that follows is indebted to André Gaudreault and Philippe Marion's discussion of intermediality as a historical category. In a series of publications that chiefly concern early film history, Gaudreault and Marion propose the model of a 'double birth' of technological media form. They distinguish between two stages in the emergence of a media form: the appearance of a new technological apparatus, and the formation of professional procedures and institutions that typify the practices of the new medium. According to Gaudreault and Marion, the two stages differ in their management of the emergent medium's intermedial relationship with other existing media forms. First, new media technologies are characterized by 'spontaneous intermediality,' as they are absorbed in the cultural context of other media forms and merely serve old established media practices. After having developed its own unique characteristics and being acknowledged as an autonomous media form, the new medium enters the later stage of 'negotiated intermediality' and creates relationships of exchanges, interconnections and borrowings with other media forms. ${ }^{8}$ In what follows, I propose that the historical scope of Gaudreault and Marion's model may be extended to also include the periods of speculation and imagination that precede the appearance of the technological apparatus.

Focusing on the commonalities and the dissimilarities of the three scenarios of televisual inventions in the three Tom Swift books, I demonstrate that the technological imaginaries themselves relate to their surrounding mediascape in different manners at different historical moments.

\section{The Tom Swift Adventuresin Their Cultural and Intermedial Context}

Communication historian Susan Douglas has argued that Tom Swift's character is "the apotheosis of the boy inventorhero." An American popular cultural archetype of the early twentieth century, the boy inventor-hero reconciled the sense of adventure associated with the contemporary thriving physical culture and the pursuit of skill-sets and education relevant for the modern world. The boy inventor-hero archetype came into being as a young fictional version of a character type initially developed by the American press in celebrating the technological achievement and charisma of inventors such as Thomas Edison and Guglielmo Marconi. According to Douglas, the press turned the inventor-hero model into a stock character, using it to humanize technology and provide reporters with "a narrative structure within which to embed the more abstract aspects of science and inventing that often defied conventional storytelling." 10

\footnotetext{
7 Molly W. Berger, 'Popular Culture and Technology in the Twentieth Century' in Carroll Pursell, ed., A Companion to American Technology, Blackwell Publishing, 2004, p. 387

8 See André Gaudreault and Philippe Marion, 'A Medium is Always Born Twice...' Early Popular Visual Culture, 3, 1, May 2005, pp. 3-15.

9 Susan J. Douglas, Inventing American Broadcasting, 1899-1922, Johns Hopkins University Press, 1987, p. 193.

10 Douglas, Inventing American Broadcasting, p. 27
} 
Popular fictional narratives on boy inventors, similarly, played a role in bringing technological invention closer to the world of American boys. ${ }^{11}$ They glorified the inventor's characters for their ability to master the environment through control of technology and to turn what would otherwise be a baffling experience into a playful adventure.

Tom Swift was by no means the first boy inventor hero in American juvenile literature. For example, already in the 1890s, a Thomas Edison inspired character named Tom Edison Jr. appeared in several adventures stories and books. But the Tom Swift series was probably the most popular and long running of its type. The series originated as an emblematic product of mainstream American popular commercial culture. The first cycle of books in this series included forty titles published between 1910 and 1941, and according to some estimates sold around fifteen million copies. ${ }^{12}$ They were produced by Edward Stratemeyer's Literary Syndicate, a book series empire founded in 1906 that worked according to a most efficient business model: it produced dozens of volumes a year, all parts of ongoing series, and marketed them to book publishers who sold Stratemeyer books for prices as low as 35 cents per title. ${ }^{13}$ Generic and formulaic by design, the books of the series were written quickly and cheaply by hired ghostwriters of the Syndicate according to given plotlines and established sets of rules. The first books in the series, for instance, were reportedly written by Howard Garis, though like all Tom Swift books they appeared under the name Victor Appleton, a company pseudonym.

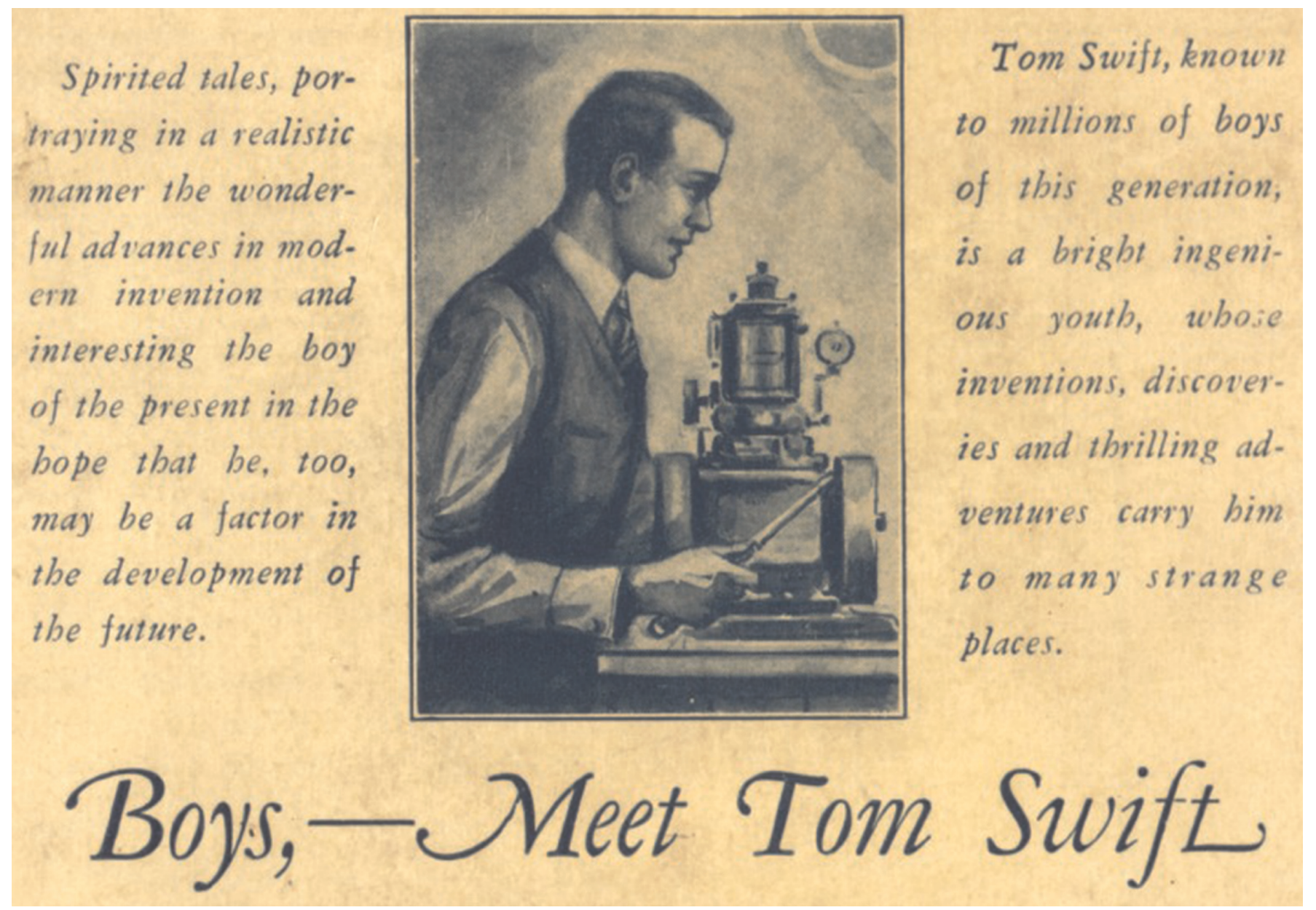

Figure 1. An advertisement for the Tom Swift series. Source: http://stratemeyer.org/2015/05/how-tom-swift-invented-everything/

11 For a discussion of gender in the Tom Swift books, see 'Desire and the Literary Machine: Capitalism, Male Sexuality, and Stratemeyer Series Books for Boys,' Men and Masculinities 3.2, October 2000, pp. 168-186.

12 Ken Donelson, 'Nancy, Tom and Assorted Friends in the Stratemeyer Syndicate Then and Now,' Children's Literature, 7, 1978, pp. 25-26.

13 Donelson, 'Nancy, Tom and Assorted Friends in the Stratemeyer Syndicate Then and Now,' pp. 17-44; Deidre Johnson, 'Juvenile Publications' in Christine Bold, ed., The Oxford History of Popular Print Culture Vol. 6, Oxford University Press, 2012, pp. 293-315. 
The Tom Swift books clearly differ in several respects from the late nineteenth century science fiction or utopian (and dystopian) novels that are more commonly considered in relation to early depiction of imaginary media forms - such as, and most famously, The Future Eve by Villiers de L'Isle-Adam and The Twentieth Century by Albert Robida. ${ }^{14}$ While the latter works speculated about future technologies in order to characterize a possible future world and offer social commentary on the present processes of modernization, the Tom Swift stories take place in the contemporary United States of America and engaged with modern invention primarily as a means to convey conservative values. Their plots celebrate individualism and nationalistic sentiments, often revolving around conflicts with enemies who are clearly marked as national or ethnic 'others' and containing a range of racial and chauvinistic stereotypes. The novels depict Tom as an embodiment of American bourgeois ideals. A white upper-middle class teenager from a small town in New York State, Tom is presented as a bright, industrious, brave and patriotic young man. A self made entrepreneur, Tom has no formal education, but his brilliance and willingness to take risks brings him to remarkable achievements, while he also enjoys the financial backing of his wealthy friends and his father, himself a successful inventor. Later books in the series depart from the individual independent inventor model in favor of telling a success story, as the young inventor develops his own advanced workshop and employs several servants and helpers.

Although the Tom Swift books focus on stories about inventions of technological novelties, they do not pursue any speculations regarding how new technologies could change the world or create alternative social conditions. The books' "marvelous development that is coming in the future," in other words, appears very consistent with the current order. As I exemplify further in the case studies below, Tom Swift's inventions are put to use in a rather limited fashion in order to combat his enemies or to be sold for profit, thus reaffirming time and again the integrity of the capitalist system. Among the numerous inventions featured in the book series, some change in the trend is clearly recognizable: the earlier books concern the invention of transportation devices, including a motorcycle, different kinds of boats, and an airship. Following these, in line with the period's rapidly growing application of electricity in daily life in the United States, the series focused more regularly on electrical inventions, depicting a remarkable range of real and imaginary modern technologies from a rechargeable battery and a wireless transmitter to an electric rifle and a giant magnet.

Having been in the public's imagination for several decades by that moment, television presented itself as an ideal subject for such popular narratives of invention. It is not surprising therefore, that among these many Tom Swift inventions, the series' authors returned to the theme of televisual novelties on three different occasions in 1914, 1928, and 1933. As some media historians have shown, the first ideas about the electric transmission of moving images and sound originated in the late 1870s, shortly after the introduction of the telephone, and ever since then remained a highly anticipated invention. ${ }^{15}$ During the late nineteenth and early twentieth century, scientists and engineers worldwide labored on developing televisual technologies; European and American newspapers routinely published items about the medium's imminent arrival as well as hoaxes about inventors who supposedly created such devices; numerous science fiction novels and short stories depicted future worlds where television was ubiquitous. Against the background of this cultural interest in the future medium, television was an easily recognizable object for the invention-adventure stories. Moreover, the rapid shifts in the media landscape that typified the period during which the Tom Swift books were published offered time and again fresh contexts and possibilities for new narratives of invention.

\section{The First Invention: Durable and Visible Telephone Conversations}

Tom's first moving image transmission invention, depicted in the 1914 novel Tom Swift and His Photo Telephone, or The Picture that Saved a Fortune, is not a domestic entertainment medium, nor a broadcast medium. Rather, it is an auxiliary device for the telephone. As Tom describes it in the book,

14 See Villiers de I'Isle-Adam, Tomorrow's Eve, University of Illinois Press, 1982; Albert Robida, The Twentieth Century, Wesleyan University Press, 2004

15 See as examples the discussion of early television histories in William Uricchio, 'Television's First Seventy-Five Years: The Interpretive Flexibility of a Medium in Transition,' in Robert Kolker, ed., The Oxford Handbook of Film and Media Studies, Oxford University Press, 2008, pp. 286-305 and

Siegfried Zielinski. Audiovisions: Cinema and Television as Entr'actes in History, Amsterdam University Press, 1999. 


\section{VIEU}

D. Galili, Tom Swift's Three Inventions of Television

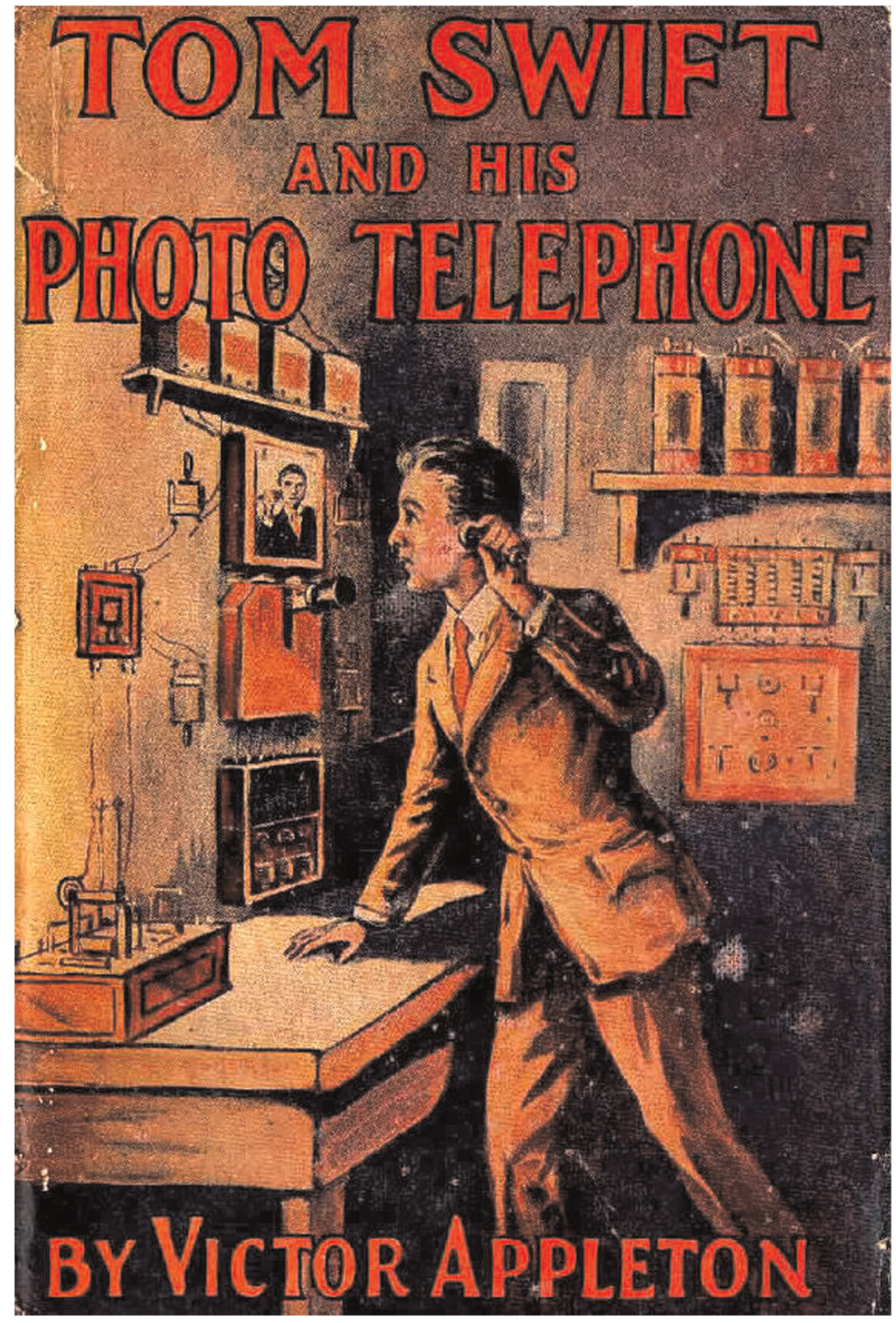

Figure 2. Cover image of Tom Swift and his Photo-Telephone, 1914.

What I'm aiming at is to make an apparatus so that when you go into a telephone booth to talk to a friend, you can see him and he can see you, on a specially prepared plate that will be attached to the telephone. ${ }^{16}$

Just like Thomas Edison, Swift's intent in creating the photo-telephone is to fabricate a practical device for the business world, particularly in order to prevent fraud. "Think of the big business deals that could be made over the telephone if the two parties could not only hear but see each other," he tells his father, "It would be a dead sure thing then."17

In 1914, the concept of a visual telephone was by no means novel, as most of the initial concepts of moving image transmission came into being as a complement for telephonic communication. ${ }^{18}$ During the previous three decades, several inventors demonstrated photo-telegraphic technologies for the scanning and transmission of still photographic

16 Victor Appleton, Tom Swift and his Photo-Telephone, Grosset and Dunlap, 1914, p. 9.

17 Appleton, Tom Swift and his Photo-Telephone, pp. 9-10.

18 On the telephonic origins of television, see William Uricchio, 'Television's First Seventy-Five Years: The Interpretive Flexibility of a Medium in Transition.' 
images by wire or wirelessly. It was not until the mid-1920's however, that the electric transmission of moving images proved feasible. Indeed, the first line in the novel consists of a quote from the young inventor's father exclaiming, "Tom, I don't believe it can be done!" Tom, of course, succeeds in fabricating the device, or at least one variant of it. The inventor conceives of the photo-telephone as possibly functioning according to two different modes of operation. On the one hand, he wants the device to function "like a mirror or a telescope," that is, to instantaneously transmit moving images by the telephone wire thereby facilitating two-way instantaneous visual telecommunication. But on the other hand, he also wants to give the photo-telephone the ability to clandestinely take a picture of the remote party in the conversation and print it on a photographic print, thereby creating a permanent record of the image seen at a distance.

While Tom is working on his invention, his friend Mr. Damon has gone missing. Soon after the disappearance, Mrs. Damon receives a phone call from a stranger who demands that she signs off her rights on some property in exchange for her husband's release. In an attempt to rescue his friend and, no less importantly, his family's fortune, Tom sets up a trap that would allow him to identify and capture the anonymous caller and provide him with indisputable evidence against the criminal. By that point in the plot, Tom only perfects the photo-telephone's transmitting still camera, and he goes on to install it in the phone booth from where he suspects the kidnapper makes his calls. Finally, he makes the multimedia trap complete by also attaching a phonograph to Mrs. Damon's telephone, so that it records the conversation with the kidnapper while the camera transmits his picture. The story ends, unsurprisingly, with Tom's victory. The transmitted photograph allows him to identify the kidnapper, and in the end of an inevitable climactic airship chase to capture him and set Mr. Damon free. The records of the blackmailing, in turn, are given to court when the criminal is finally arrested. As the judge who signs the warrants remarks "it's a new way of convicting a man - by a photo telephone - but I guess it's a good one."19

Ultimately, then, the invention at the center of Tom Swift and His Photo Telephone takes various forms. Similar to many real inventors before him, including Paul Nipkow and Thomas Edison, Tom initially conceives of the televisual device as an auxiliary of the telephone that accompanies the telephonic transmission of sound with the transmission of moving images. $^{20}$ In this sense, to use Gaudreault and Marion's term, the photo-telephone appears to be an extension of the telephone, a new technological device that is put to use in existing media practices. Tom's motivation in this case is to complement the telephone; to reinforce its reliability for business exchanges by compensating for the 'blindness' of the aural medium. Indeed, as several commentators have noted, the possible misuse of the anonymity of the telephone became a social concern around the turn of the twentieth century, and informed some of the early technological imaginations of visual telephony. ${ }^{21}$ However, the photo-telephone ends up taking a different form and serving quite a different function in the adventure plot. While it starts as an apparatus that adds a visual dimension to telephonic aural telecommunications, the adventure plot requires Tom to drop the initial idea of live moving image transmission and instead construct a more sophisticated assemblage that consists of telephones, a photo-telegraphic device and a phonograph. The resulting compound medium defies traditional definitions of media: it is at once a sound and image medium, a transmission and a recording medium, and a two-way and one-way communication. Quite literally, the novel situates two media against one another: while the telephone serves the criminal's extortion scheme, Tom's new compound medium allows rescuing Mr. Damon and restoring order.

Strikingly, unlike the initial idea of an instantaneous moving image transmission device that aims at complementing the telephone, the compound medium that eventually 'saves the day' is designed as an anti-telephone. The novel power of Alexander Graham Bell's invention was its ability to separate one's voice from their living visible body and enable real time long distance reproduction of transient sounds. Tom's invention undoes both: it renders the telephone user visible and makes a permanent record of the spoken words. And so, the invention that started out as an extension of the telephone, ended up being a technology that counters its possibilities: Tom has to use a new technology in order to neutralize, or simply un-do, the potentially disturbing effect of an existing technology.

19 Appleton, Tom Swift and his Photo-Telephone, p. 197.

20 'What Mr. Edison Noticed in Europe,' Scientific American, October 19, 1889, p. 249; Paul Nipkow, "Der Telephotograph und das elektrische Teleskop," Elektrotechnische Zeitschrift 6, October 1885, pp. 419-425.

21 See Carolyn Marvin, When Old Technologies Were New, Oxford University Press, 1988, and Ithiel de Sola Pool, Forecasting the Telephone: A Retrospective Technology Assessment of the Telephone, Ablex Publishing, 1983. 
D. Galili, Tom Swift's Three Inventions of Television

\section{The Second Invention: Talkies in the Air}

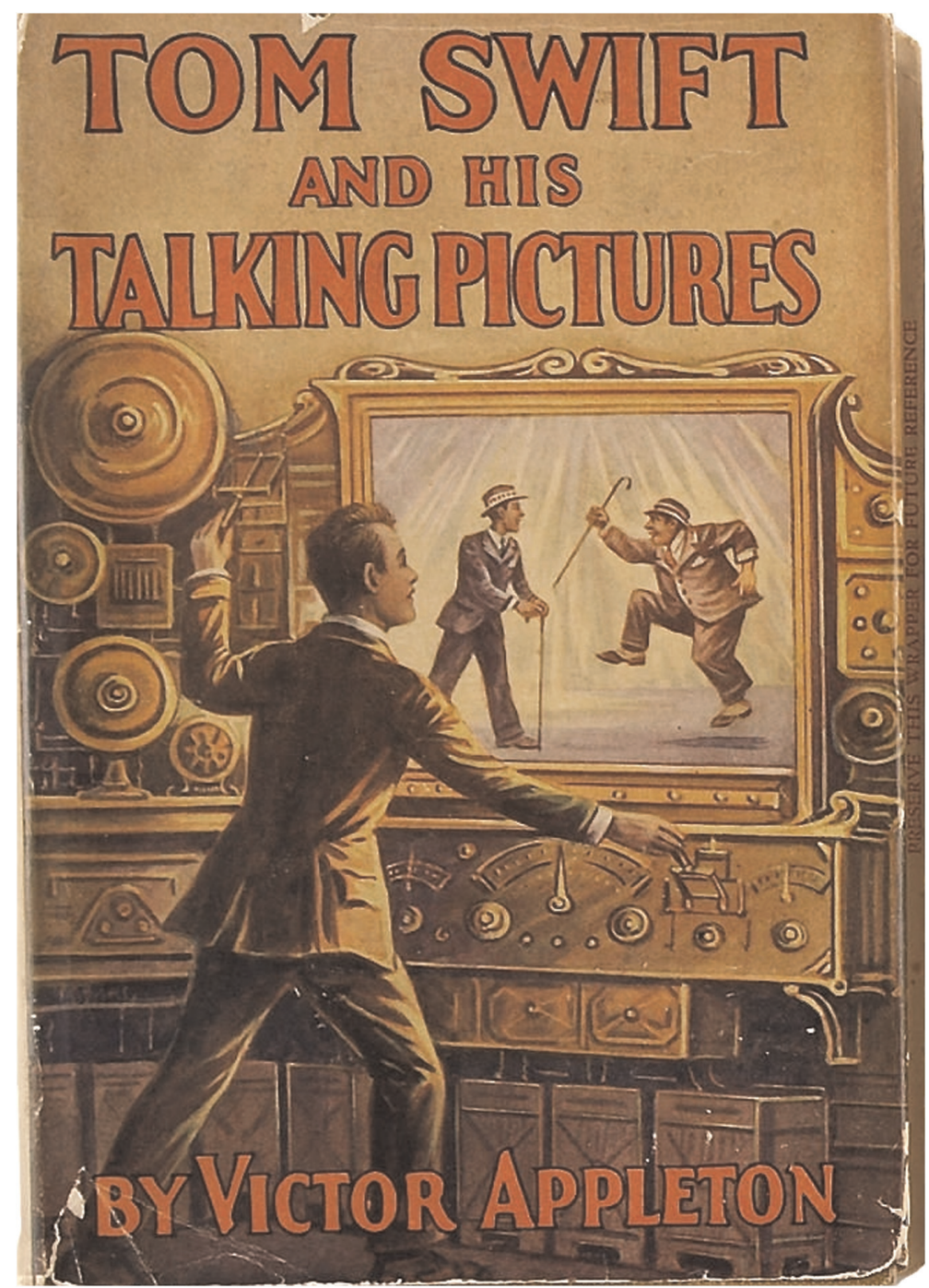

Figure 3. Cover image of Tom Swift and His Talking Picture, 1928.

If Tom Swift's first invention of an image transmission medium helped him resolve a crisis, the invention featured in Tom Swift and His Talking Pictures, or The Greatest Invention on Record is rather a cause for a crisis. Published 14 years after the photo-telephone adventure, the second Tom Swift novel features a new variant of a moving image transmission medium. This time, Tom's motivation in creating the invention is strictly financial, and he designates it purely for entertainment purposes. In fact, the talking pictures device is very much like what we have come to refer to as a TV set: it is an electronic large screen device that enables the domestic reception of live transmissions of music and performances from distant theatres. The novel explicitly mentions the earlier invention of the photo-telephone as an ancestor of the talking pictures device. Yet, in the plot that takes place in the late 1920s - the era of radio networks and classical Hollywood - the telephone no longer provides the intermedial reference. Rather, the talking pictures are considered as extensions of both the radio and the motion pictures, or, as Tom's rival describes it, the invention "make [s] pictures appear inside a radio machine!"22 This way, the difference between the photo-telephone and the talking pictures inventions signifies a profound change in the very meaning of the term 'transmission': the photo-telephone enables two-way visual communication between two devices that relay images to one another; the talking pictures, 
conversely, is not only a wireless transmission medium, but also a broadcasting medium, which transmits audiovisual materials from one central transmitter to a potentially infinite number of corresponding receiver devices that Tom intends to sell to his costumers. In other words, the invention is a new technological application of wireless communication that enables a new business model for Tom's enterprise.

While indicating the talking picture's intermedial affinities, the novel also emphasizes the dissimilarities between the new device and existing media technologies. Tom mentions specifically that his invention is superior to television. Indeed, the imagined medium that is described in the novel is a far cry from the state that television was in during the late 1920s. Inventors such as Baird had succeeded in constructing working prototypes of television, but those were still far cruder, slower, smaller, and in lower-resolution than Tom's invention. Interestingly, the novel stresses the fact that the talking picture device was not the same as the sound film. As Tom claims, it "was not to be confused with some moving and 'talking' pictures, which are a combination of film and phonograph records, working simultaneously." ${ }^{23}$ Anticipating the discourse around 'liveness' in early American television by about twenty years, the novel maintains that the talking pictures resemble the experience of watching a theatrical show, since with it one may "see and hear the actual theatre play, a complete vaudeville show, or even a complete operatic performance," and therefore must not be associated with audiovisual reproduction of 'canned' images and sound. ${ }^{24}$

Tom Swift and His Talking Pictures, however, is invested more in telling an adventure story than in proposing meticulous medium-specific argumentation. During the final stages of the perfection of the new technology, Tom's lab is under an attack from unknown saboteurs. Tom suspects that the saboteurs work for theatre owners, as they communicate to him that "we're not going to let you make a machine that will permit folks to sit at home and see and hear a show without paying the admission price. Not in a thousand years!" 25 Unabated, Tom continues his experimenting with the new technology and succeeds in broadcasting a song and dance number in full color on a large screen. As his enemies continue their attack, the adventure plot becomes an all-out capitalist competition, or as Tom puts it, the struggle is about "who means the most business." 26 To put it differently, if in the earlier book in the series Tom uses the photo-telephone as part of his efforts to act against his enemy, the main plot of The Talking Pictures is essentially a dramatization of a competition between Tom's new medium and the established 'old' media.

Even more striking is the manner in which the novel presents the conclusion of the conflict. After several attacks, Tom tricks the saboteurs into meeting him and discovers that they are indeed a group of executives from the film and theatre industries motivated by their concern about the risk his invention poses on their trade. Giving up on their attempt to scare Tom off of finalizing his technology, the executives offer him 1,000,000 dollars for the rights to the machine so they could destroy it and continue with their business free of its threat. As they claim, "Do you think [...] we want people to stay at home listening to music and seeing pictures of a performance on your screen? Where would we be if millions of people did with pictures what they are doing right now with their radio receivers? We'd be ruined in six months." 27 Tom, however, is convinced that the machine will prove to be "a delight to humanity" and would not let it be destroyed. ${ }^{28}$ Although he has the option to report the executives to the police, he chooses to collaborate with the theater and film business. Not only is he in need of capital to continue the manufacturing of the talking picture device, he is also aware of his dependence on theatre and film productions, for without them he would have nothing to broadcast. The adventure story that started with the invention of a new technology and continued with a depiction of an all-out war between old media and new media thus concludes with a media convergence deal: Tom sells the theatre and film industry half of the shares of his company for triple the amount they initially offered and gets to continue his pursuits with no threat of competition. The media rivalry is settled, and although the novel presents a demonic portrayal of the film business, Tom's new mass medium of the talking pictures does not only find its place alongside film and theatre, but also profits from them.

23 Appleton, Tom Swift and His Talking Picture, p. 120.

24 Appleton, Tom Swift and His Talking Picture, p. 121. On early discourses of television liveness and its relation to theatre, see Philip Auslander, Liveness: Performance in a Mediatized Culture, second edition, Routledge, 2008 pp. 11-24 and Lynn Spigel, Make Room for TV: Television and the Family Ideal in Postwar America, University of Chicago Press 1992, pp. 99-145.

25 Appleton, Tom Swift and His Talking Picture, p. 89.

26 lbid., p. 148.

27 lbid., p. 188.

28 Ibid., p. 191. 


\section{The Third Invention: A Television Turned Inside Out}

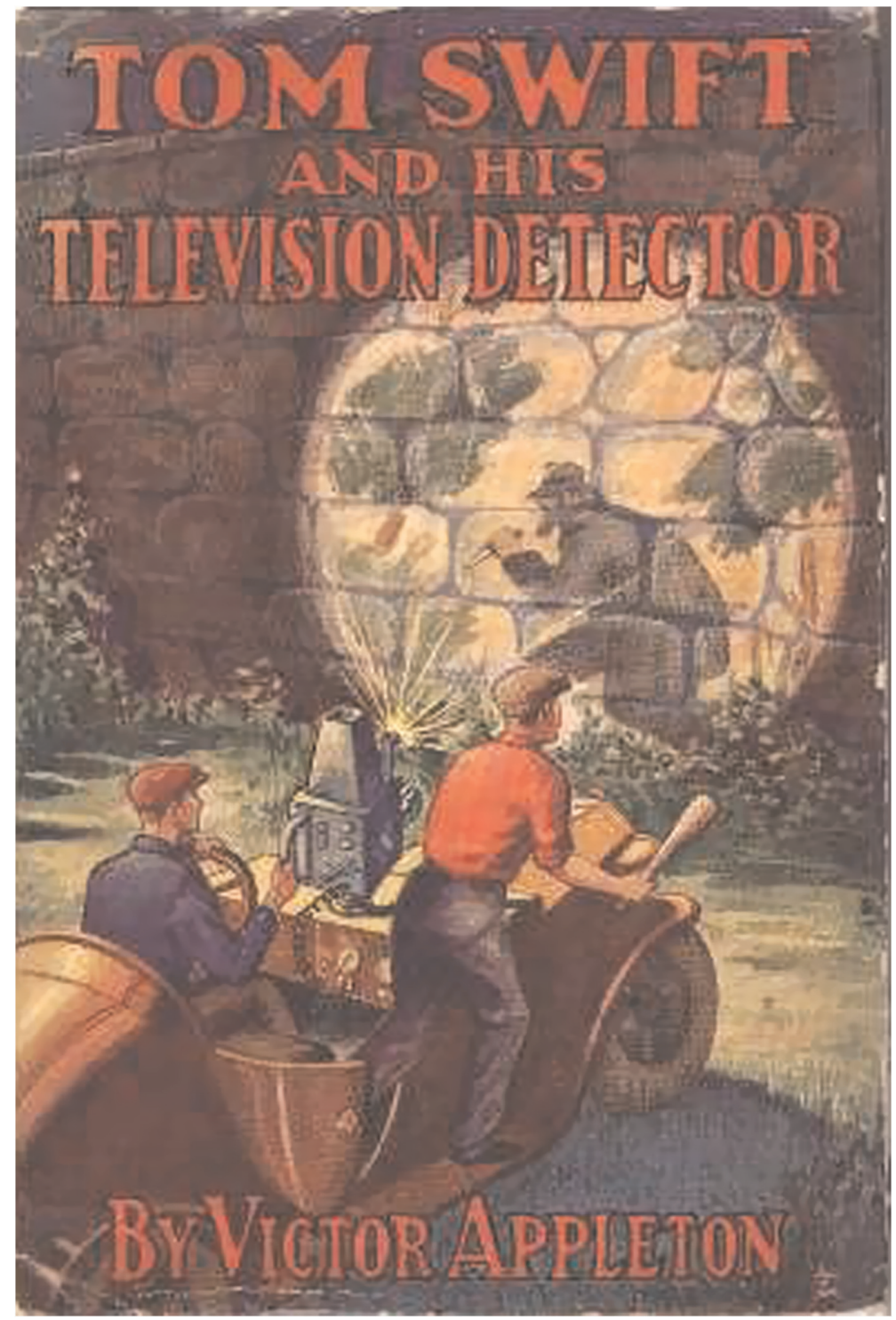

Figure 4. Cover image of Tom Swift and His Television Detector, 1933.

The 1928 Talking Pictures novel thus presented an imagined form of television that very closely resembles the mass media practices emerging in several countries during the 1930s. Yet, the 1933 novel Tom Swift and His Television Detector, or Trailing the Secret Plotters continued the speculations about other possible formations of visual transmission technologies and presented what is perhaps the most fantastic variant of Tom's three televisual inventions. By the early 1930s, television technology was developed and operated by major electronics corporations and radio networks, and was no longer a business for an individual inventor - no matter how capable or heroic. Tom's television detector, accordingly, is rather a portable surveillance technology that enables seeing in dark and though walls and other obstacles, and is useful, "to find something secret, hidden, stolen or even someone kidnapped." ${ }^{29}$ Tom invents the television detector in parallel to another new invention, a portable wireless telegraphy device, which is meant for sending emergency signals, for instance in the event that someone gets kidnapped. The novel only provides a partial explanation for how the device operates, noting that it consists of a "double anode, high vacuum, cathode ray 
oscillograph tube" which projects radiation akin to X-rays and, in turn, displays on the device's screen an image of the objects it illuminates. ${ }^{30}$

In accordance with the politics of its times, the novel's plot concerns an attempt to capture a cunning foreign anarchist, to return a formula for deadly gas that an unknown rival has stolen from Tom, and to rescue his colleague who was indeed kidnapped while carrying the portable wireless telegraphy device. In all these pursuits, naturally, the television detector proves indispensible. Tom, working in collaboration with a secret service agent, uses the instrument to locate his enemies even when they are hiding in dark caves, and trace the whereabouts of the imprisoned colleague. The story ends with Tom thinking of further possible developments for the television detector, which involves increasing its range of radiation to a full 360 degrees.

Admittedly, the storyline and the deployment of the detector seem to have little to do with television in the way it was commonly understood in the 1930s (beyond, perhaps, the literary meaning of 'seeing at a distance'). Yet, the novel emphasizes that the invention belongs within the lineage of Tom's previous televisual devices, as it depicts Tom as a media archaeologist who digs up old obsolete devices in order to realize a new technological construct. Early on in the novel, Tom tells one of his colleagues that "both my photo-telephone and my talking pictures embodied features of television," and at a later moment he goes to the storehouse in order to retrieve parts from the old machines in order to reuse them in the construction of the new detector. ${ }^{31}$

It is likely that the author drew inspiration from the television pioneer Baird and his recent invention of the 'noctovision,' a television system that used the illumination of infra-red radiation and displayed images with no visible light illumination. ${ }^{32}$ It is also possible that the affinities between X-ray tubes and the cathode ray tubes of electronic television invited speculations about all-seeing television technology with a piercing gaze. Either way, Tom's television detector marks an attempt to capitalize on the contemporary interest in the coming of television and to offer a fictional story of an invention that out-does what even the most advanced television technologies of the time could. What is curious, however, is that the television detector's operation is in a sense a complete opposite of that of broadcast television. To put it differently, Tom does not invent a new television, but rather turns 'real' television inside out: broadcast television, fundamentally, is a technology that delivers moving images of the outside world to viewers confined in the fixed enclosed location of the home (Raymond Williams famously related to this capacity of broadcasting as 'mobile privatization' ${ }^{33}$ ). Tom's television detector, conversely, is a mobile technology that allows its users to look from the outside, while in motion, into homes and other enclosed private spaces. Once again, therefore, similar to the set-up of the anti-telephone compound in the 1914 novel, Tom's televisual invention takes up an existing technology as its model and reconfigures it in a radical fashion.

\section{Imaginary Media and the Archaeology of Television}

This account of the various Tom Swift televisual adventures demonstrates several points that may shed additional light on our understanding of the technological imaginary of television. First and foremost, the Tom Swift novels are significant in demonstrating the multiplicity of ideas that existed about televisual media before the public inauguration of regular television services. In and of itself, the fact that different competing views about television existed early on in the medium's history is of course not new. Several commentators had written about how different social groups may hold multiple distinct conceptions regarding an emergent technology. ${ }^{34}$ However, in the case of the Tom Swift novels, it is the very same book series, holding continuously to the same rigid capitalist ideology, that features markedly different views on the future possibilities and properties of image transmission media during the period of two decades. In concert with

32 'Noctovision New Electric Miracle,' Daily Boston Globe, May 2, 1928, p. 31.

33 Raymond Williams, Television: Technology and Cultural Form, Routledge, 2003, pp.19-21.

34 See, for example, Lisa Gitelman, 'How Users Define New Media: A History of the Amusement Phonograph' in David Thorburn and Henry Jenkins, eds., Rethinking Media Change: The Aesthetics of Transition, MIT Press, 2004, pp. 61-79. 
one of the basic assumptions of the media archaeology approach, what this multiplicity indicates is that it would be wrong to consider a unified and linear 'pre-history' of television, since some of these early imaginary ideas significantly differ from those of domestic broadcasting that eventually came to typify the dominant use of television.

As Thomas Elsaesser writes regarding applying the media archaeology approach to the study of cinema, "film history is best described as a series of discontinuous snapshots that illuminate a whole topography: the task is to map this field as a network, rather than as discrete units. ${ }^{35}$ The three televisual inventions featured in the Tom Swift series may be seen as such, three snapshots that shed light on possible ideas of television in different moments. But rather than leaving the moments discrete, the books quite literally serialize them. By doing so, as I have shown, what the books sketch is not a seemingly linear trajectory, but rather a network that defies fixed notions of media specificity and that indeed charts various links that tie the different television variations to a wide range of other media of communication, entertainment, and surveillance. ${ }^{36}$ The fact that televisual devices could be invented and re-invented time and again in such different manners in the three novels reveal that the anticipation of audiovisual transmission media was not based on a monolithic concept, but rather changed and updated its parameters according to available media and existing cultural practices.

Furthermore, the three Tom Swift novels suggest that Gaudreault and Marion's model, which considers the dynamics of intermedial affiliations and gradual development of specific properties in the early stages of a medium's history, is suitable also for discussions of earlier stages in a medium's history when applied to the imaginaries of technological media. Throughout the novels from 1914, 1928 and 1933, Tom invents, re-invents, and re-positions his novelties within an existent mediascape. In all three novels, the development of the televisual inventions follows essentially the same scenario. Time and again, Tom first conceives of a new technology that complements other, existing media: first, he seeks to add a visual dimension to telephone conversations; then, he adds pictures to radio broadcasts; and finally he improves a combination of the former two inventions in order to create a powerful surveillance device. Following this, each novel depicts certain plot complications that serve to demonstrate the superiority of Tom's current technological novelty over other media (by allowing it to identify and incriminate the extortionist who exploits the telephone in his scheme, by bringing the film business to their knees and making them finance the talking pictures and provide content for it, and by locating the anarchist using the portable detector's x-ray qualities). These scenarios, I would argue, parallel the historical process Gaudreault and Marion describe, in which a new technological medium first appears as an extension of other older media and only through developing a set of protocols and codes dissimilar from those deployed by other media establishes its own specific identity.

However, fictional stories about imaginary media offer something else beyond providing a schema for media genealogy: they also embed the nonexistent media within a narrative framework. By integrating the fictional televisual inventions none of which, as I have shown, an original idea - into the adventure stories, the Tom Swift novels discuss them in relation to a specific social context and to other technologies and cultural phenomena. The novels thus should be read as real-time popular commentary on the mediascape of early twentieth century, which consists of vernacular speculations regarding authenticity and evidential values, epistemologies of mediated vision, the capitalist market of media innovations, and, time and again, the impact of new inventions on the existing mediascape.

In closing, it is worth mentioning yet another, fourth televisual invention of Tom Swift - or, more accurately, of Tom Swift Jr., the hero of a follow-up series published between 1954 and 1971, and attributed aptly to Victor Appleton the second. The space-age Tom, inventor or rocket ships and robots, introduced in a 1964 novel a three dimensional television system, dubbed 'telejector.' Taking a considerable step forward from the state of television in the mid-1960s, the telejector is capable of projecting videotaped images without a screen right into a room by using a chemical mist as its physical support (or even right into space, using space dust instead). ${ }^{37}$ While this novel goes beyond the

35 Thomas Elsaesser, 'Early Film History and Multi-Media: An Archaeology of Possible Futures?,' in Wendy Hui Kyong Chun and Thomas Keenan, eds., New Media, Old Media: A History and Theory Reader, Routledge, 2006, p. 17

36 The ongoing construction of different television variants demonstrates the medium's 'interpretative flexibility,' its ability to be envisioned in different manners by different social groups in different historical moments. On the concept of 'interpretative flexibility' see Wiebe E. Bijker, Thomas P. Hughes, Trevor Pinch, eds., The Social Construction of Technological Systems: New Directions in the Sociology and History of Technology, MIT press, 2012. 37 Victor Appleton II, Tom Swift and His 3-D Telejector, Grosset \& Dunlap, 1964. 
D. Galili, Tom Swift's Three Inventions of Television

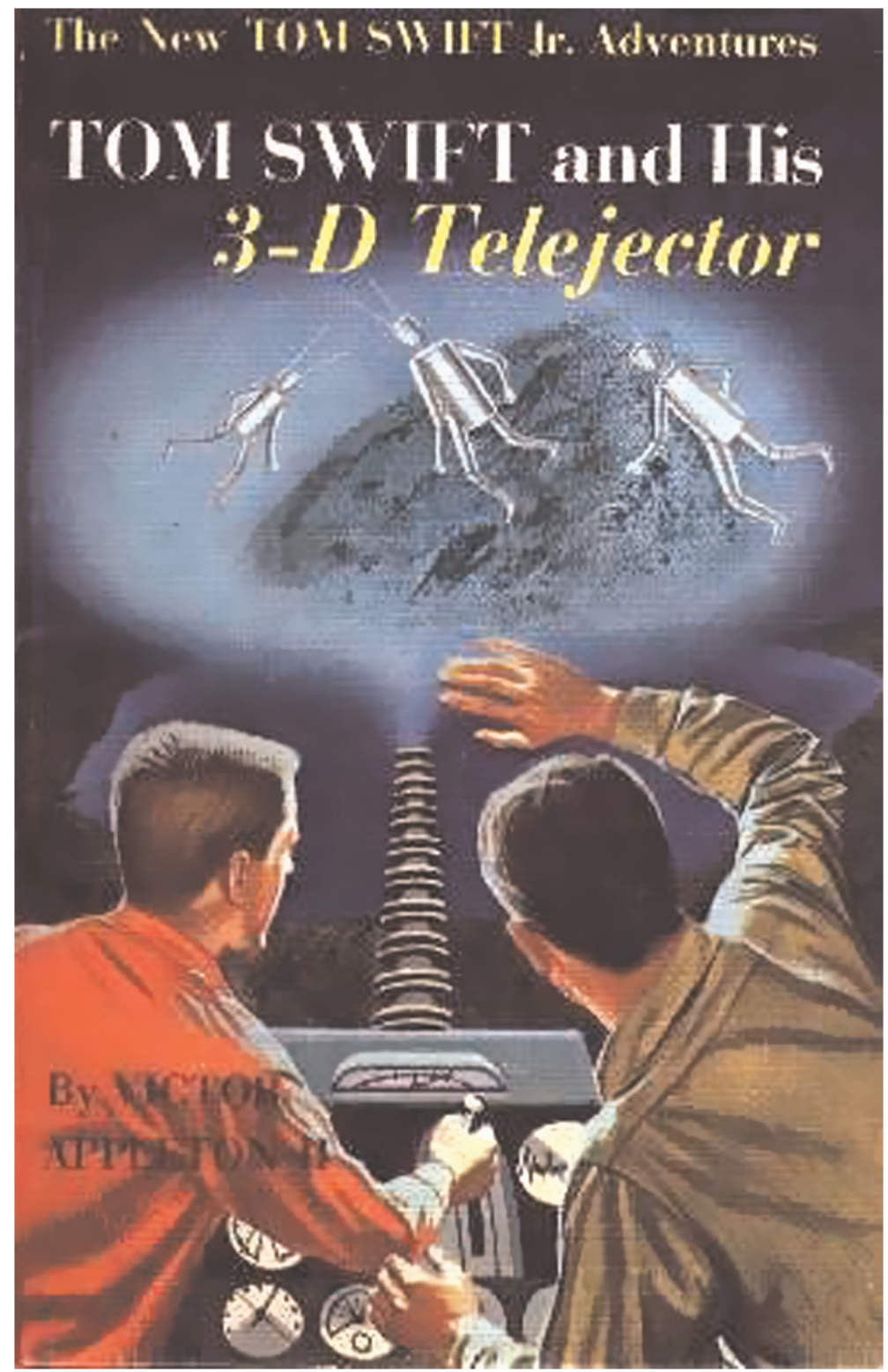

Figure 5. Cover image of Tom Swift and His 3-D Telejector, 1964.

historical scope of this article, it is a good reminder that although the technological imaginary is a useful concept for the study of the origins of media, new imaginary forms continue to present themselves throughout a medium's history in response to new historical situations, further broadening the scope of the network of intermedial relations awaiting to be charted.

\section{Acknow ledgements}

I want to thank the journal editors and article reviewers for their insightful comments, and Christina Petersen for introducing me to the Tom Swift novels and discussing them with me. 
D. Galili, Tom Swift's Three Inventions of Television

\section{B i o graph y}

Doron Galili is a postdoctoral researcher in the Department of Media Studies at Stockholm University. He holds a PhD in Cinema and Media Studies from the University of Chicago and an MA in Moving Image Archive Studies from UCLA. His dissertation, "Seeing by Electricity: The Emergence of Television and the Modern Mediascape, 1878-1939," received an honorable mention for the 2013 SCMS dissertation award. 